\title{
Forest management strategies to reduce spruce budworm damage in the Fundy Model Forest ${ }^{1}$
}

\author{
by David A. MacLean ${ }^{2}$
}

Spruce budworm (Choristoneura fumiferana) outbreaks cannot be prevented, but the amount of damage that occurs can be managed. Tree species, stand age, hardwood content, and drainage class, as well as the outbreak severity and length, determine the amount of tree mortality during budworm outbreaks. Silviculture and forest management can be used to reduce the incidence of the most damaged stand types across the landscape. The amount of defoliation in mixed balsam fir-hardwood stands is strongly negatively related to hardwood content, especially with hardwoods $>40 \%$. The Spruce Budworm Decision Support System (DSS) links models of stand and forest response to budworm outbreaks and inventory interpretation to a GIS, and can be used to evaluate effects of outbreaks and management on forest structure and timber supply. An example using the Spruce Budworm DSS for a portion of the Fundy Model Forest indicated that losses from a future budworm outbreak could be reduced $34 \%$ by directing harvesting and silviculture towards conversion of one-half of the most vulnerable stand types into low susceptibility or non-susceptible species.

Key words: decision support system, vulnerability, silviculture, insect damage

\section{Introduction}

Spruce budworm (Choristoneura fumiferana $\mathrm{Clem}$.) outbreaks have more effect on structure and function of the spruce-fir forests of eastern Canada than virtually any other factor (MacLean 1985a, 1990). The severe defoliation that occurs during spruce budworm outbreaks reduces growth rates and can result in heavy tree mortality and loss of control of the planned sustained yield harvest pattern. This has prompted a project to develop a Spruce Budworm Decision Support System (DSS), which includes a suite of models and forest inventory interpretation systems, linked to a GIS, that can assist forest managers in making decisions regarding spruce budworm and forest management planning (MacLean and Porter 1994, 1995).

The Spruce Budworm DSS is implemented using a UNIX workstation, the ARC/Info GIS, and a graphical user interface. Specific DSS tools completed to date include an Inventory Projection System (IPS), which allows evaluation of effects of budworm outbreak and insecticide-use scenarios on the for-

${ }^{1}$ Paper presented at the "Silvicultural Approaches to Integrated Insect Management" Workshop, Entomological Society of Canada Annual Meeting, 16-19 October 1994, Winnipeg, Manitoba.

${ }^{2}$ Canadian Forest Service - Fredericton, P.O. Box 4000, Fredericton, New Brunswick, Canada E3B 5P7 and Faculty of Forestry and Environmental Management, University of New Brunswick, Fredericton, New Brunswick, Canada E3B 6C2.
Les épidémies de tordeuses de bourgeons de l'épinette (Choristoneura fumiferana) ne peuvent être prévenues, mais il est possible de faire face aux dommages qui en découlent. Les espèces d'arbres, lâge du peuplement, le pourcentage de feuillus, et la classe de drainage, ainsi que l'importance de l'épidémie et sa durée, déterminent le niveau de mortalité des arbres au cours d'une épidémie de tordeuses. La sylviculture et l'aménagement forestier peuvent Ietre utilisés pour réduire l'incidence pour la plupart des peuplements les plus endommagés. Le niveau de défoliation pour un peuplement mélangé de sapin baumier et de feuillus est forcement relié de façon négative au contenu en feuillus, surtout lorsque les feuillus $>40 \%$. Le système d'aide à la décision pour la tordeuse des bourgeons de l'épinette (DSS) permet de relier les modèles de peuplement à la réponse obtenue en forêt suite à une épidémie de tordeuse et son interprétation cartographique à un SIG, et le système peut être utilisé pour évaluer les effets d'une épidémie et de son aménagement sur la structure forestière et l'approvisionnement en matière ligneuse. Un exemple utilisant le DSS de la tordeuse des bourgeons de l'épinette pour une partie de la forêt modèle de Fundy a indiqué que les pertes occasionnées par les prochaines épidémies de tordeuses pourraient être réduites de $34 \%$ en affectant la récolte et la sylviculture à la conversion de la moitié des peuplements les plus vulnérables pour en garder les espèces à faible susceptibilité ou à susceptibilité nulle.

Mots clés: système d'aide à la décision, vulnérabilité, sylviculture, dommage d'insectes

est inventory at user-specified times in the future (DeMerchant 1994), and a Protection Planning System (PROPS), which provides a systematic methodology for designing forest protection (insecticide use) under the threat of spruce budworm, based on quantifying the marginal timber supply benefits of protecting stands (Vanguard Forest Management Services Ltd. 1993a). Another model currently under development is a vulnerability rating system that would quantify losses during budworm outbreaks, as a function of forest inventory characteristics (MacLean and Porter 1994).

The objectives of this paper are:

1. To briefly review the available data on stand vulnerability to spruce budworm and past recommendations of silvicultural and forest management strategies to reduce budworm damage. 2 . To discuss the potential role of a DSS in managing damage caused by spruce budworm outbreaks.

3 . To present an example of projected spruce budworm damage in the Fundy Model Forest, southern New Brunswick, under three scenarios (unprotected, protected using insecticides, and enhanced silviculture).

4. To describe three current projects that are providing additional data for the vulnerability rating system.

\section{Vulnerability to Spruce Budworm}

Many studies have presented data on the effects of spruce budworm outbreaks on growth, mortality, and succession (MacLean 1980, 1985a). As might be expected, both growth 
loss and mortality are strongly related to the cumulative amount of defoliation that occurs (Piene 1980; MacLean and Ostaff 1989; Ostaff and MacLean 1995). This provides a strong basis for modelling the effects of spruce budworm outbreaks on stand dynamics, and at least three models have been developed (Baskerville and Kleinschmidt 1981; Vanguard Forest Management Services Ltd. 1993b; Steinman and MacLean 1994).

More is known about effects of stand factors on tree mortality caused by spruce budworm than about effects on amount of defoliation or on the growth reduction caused by defoliation. The most consistent general trends that emerge are that tree species, stand age, hardwood content, and drainage all influence the amount of mortality during spruce budworm outbreaks.

1. Tree species strongly influences the amount of mortality that occurs, with balsam fir (Abies balsamea (L.) Mill.) $>$ white spruce (Picea glauca (Moench) Voss) $>$ red spruce $(P$. rubens Sarg.) $>$ black spruce (P. mariana (Mill.) B.S.P.) $>$ nonhost species. Average levels of mortality in mature and immature balsam fir and spruce stands, based on over 100 plots from various regions and outbreaks (MacLean 1980), are shown (Fig 1A).

2. Stand age also affects mortality, with mature and overmature $>$ immature stands (Fig. 1A). Combined effects of species and age resulted in average mortality of $85 \%$ in mature balsam fir, $42 \%$ in immature fir, $36 \%$ in mature spruce, and $13 \%$ in immature spruce stands (MacLean 1980).

3. Greater hardwood content within a stand reduces host tree mortality. MacLean (1980) found that balsam fir stands with $>20 \%$ hardwoods sustained $20 \%$ less mortality than pure fir stands. Similarly, Osawa et al. (1986) determined that stands with $>35 \%$ hardwoods sustained $40 \%$ less balsam fir mortality and $16 \%$ less spruce mortality.

4. Drainage also affects balsam fir mortality, with higher losses on excessively dry and wet sites than on more mesic sites (Fig. 1B). Dupont et al. (1991) reported balsam fir mortality of $85,75,45$, and $27 \%$ in xeric, hydric, mesic, and subhygric drainage classes, respectively. Similarly, Hix et al. (1987) reported $43 \%$ balsam fir mortality on poorly drained sites versus $34 \%$ on well-drained sites. Both Hix et al. (1987) and Osawa (1989) reported higher black spruce mortality on excessively dry than on poorly drained sites.

The above data clearly indicate that certain stand type/site combinations sustain greater damage during budworm outbreaks. This provides a first step for planning harvesting, silviculture, and planting operations, all of which can be used to discriminate against the most vulnerable types. However, the above data do not tell us the mechanisms involved in differential vulnerability. Higher budworm-caused mortality could be caused either by higher defoliation levels (indicating an effect of stand/site characteristics on spruce budworm population dynamics) and/or by differential tree response to a constant defoliation level (i.e. a greater ability to withstand or recover from defoliation). Over the long term, it is important to determine the actual mechanism involved to refine strategies, and two ongoing studies to do this are described later in this paper.

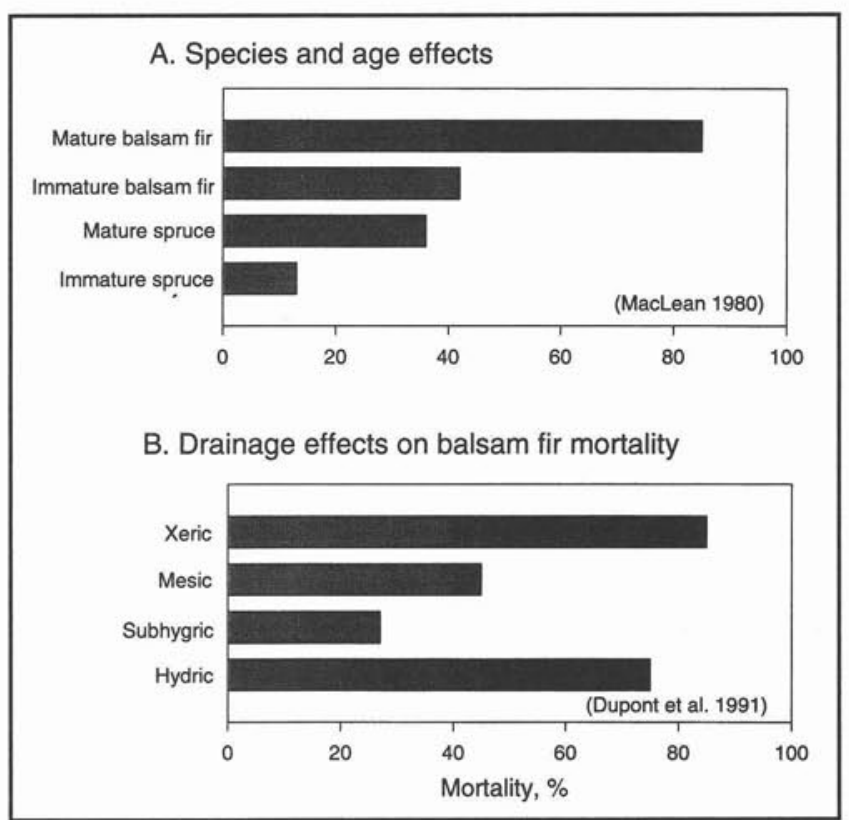

Fig. 1. Effects during uncontrolled spruce budworm outbreaks of (A) tree species and maturity on mortality, and (B) drainage class on balsam fir mortality.

Although mortality tends to be consistently high and low, respectively, in mature balsam fir and immature spruce stands, it is very variable in immature fir and mature spruce stands. Although mortality averaged about $40 \%$ in the latter two types, it varied from almost nil to near $100 \%$ in individual plots (MacLean 1980). This variability occurred spatially within stands as well, such that adjacent plots in immature balsam fir stands sometimes sustain low and very high mortality (Baskerville and MacLean 1979; MacLean and Piene 1995). This contagious pattern of mortality creating "holes" (heavy mortality areas) within stands is probably related to the spatial pattern of budworm defoliation. It means that small plots (e.g.., $<0.05-0.1$ ha or prism points with low basal area factor), that could entirely encompass or miss the mortality patches, should be avoided in surveys of budworm-caused tree mortality (Baskerville and MacLean 1979; MacLean and Ostaff 1983; MacLean and Piene 1995).

\section{Effects of Budworm Outbreak Dynamics and Forest Management}

Any spruce budworm management strategy must be based upon an understanding or paradigm of population dynamics of the insect. Repeated spruce budworm outbreaks have occurred in eastern North America, beginning around 1910, 1940, and 1970 (Blais 1983; Kettela 1983). Budworm populations oscillate in synchrony over broad areas, regardless of the level of damage to host trees, and generally reoccur on about a 30-35 year cycle. Detailed studies of spruce budworm population dynamics have demonstrated that outbreak collapse is caused by an array of parasites and diseases acting in concert to increase mortality of budworm larvae and reduce fecundity (Royama 1984, 1992).

Therefore, if in the long run, budworm will come and go independently of what is done to the forest, the major effect of sil- 


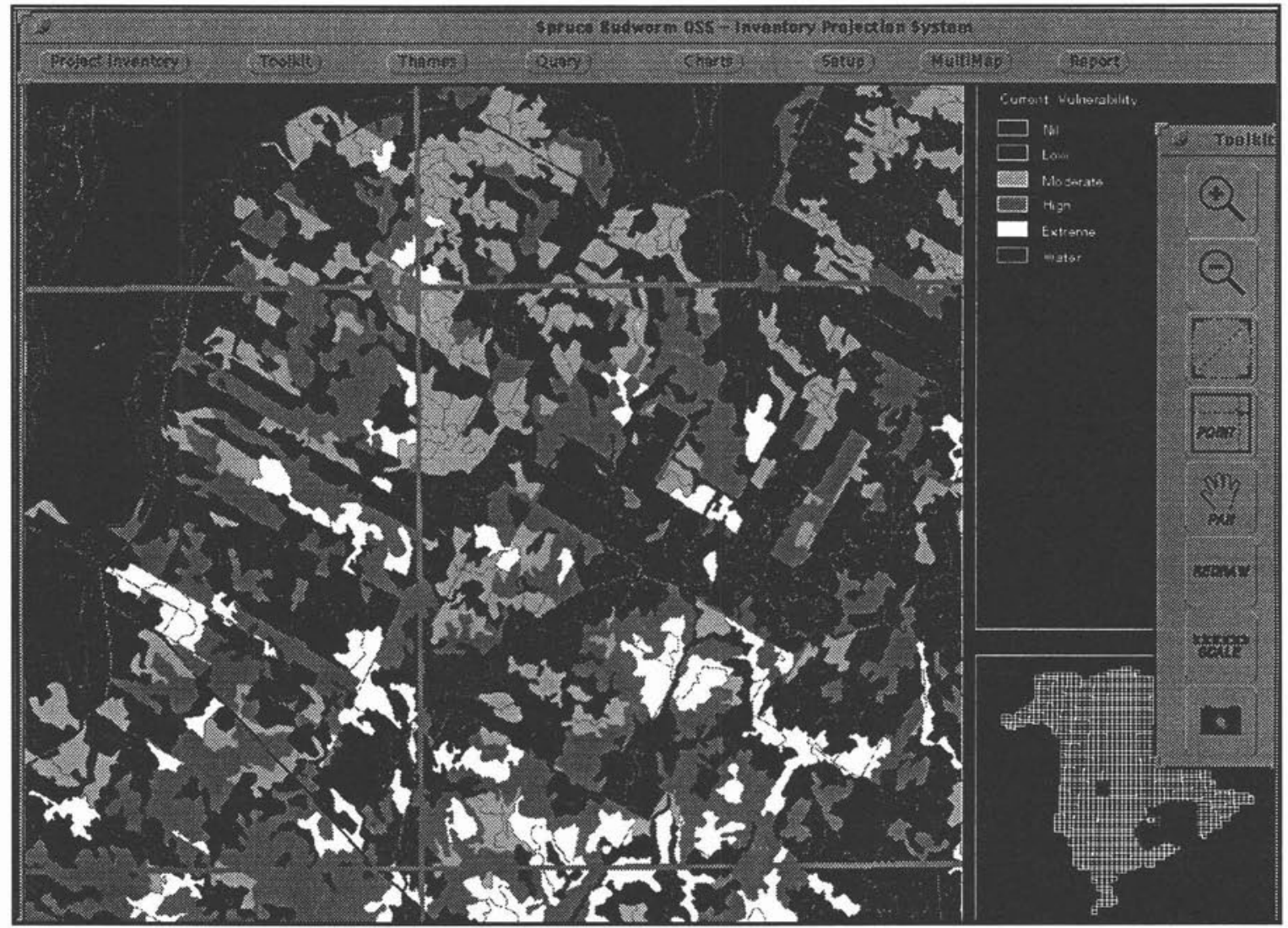

Fig. 2. View of the Spruce Budworm DSS, displayed on a Unix workstation. Buttons at the top control pull-down menus and dialog boxes; shown are the main window to display various themes superimposed on forest inventory polygons, the legend (upper right), an index map for use in selecting the area to be displayed (lower right), and the tool bar controlling functions such as zooming, fine-scale area selection, etc. In this example, the theme displayed is budworm vulnerability, using five colors or shades to represent classes of nil, low, moderate, high, and extreme.

viculture should be to buffer stands against these periodic episodes (Blum and MacLean 1984).

In terms of area affected, spruce budworm outbreaks apparently have increased dramatically in severity during the 20th century (Blais 1983). Maximum extents of the 1910, 1940, and 1970 outbreaks were about 11,25 , and 58 million ha, respectively (Kettela 1983). Even taking into account the lack of surveys or data for the first and, to a lesser extent the second, of these outbreaks, this is a dramatic increase. Three forest management activities, in conjunction with the shade-tolerant silvics of balsam fir, probably have contributed to this increase. Forest fire protection, clearcut harvesting, and insecticide use against spruce budworm have all contributed to increased balsam fir, the most severely damaged species, in the forests of eastern Canada. Balsam fir cannot survive in the presence of fire, but due to its shade tolerance and production of large numbers of seedlings under existing canopies, it regenerates prolifically following clearcuts. Even stand-killing spruce budworm outbreaks often just "recycle" mature even-aged fir stands to even-aged fir regeneration (Baskerville 1975; MacLean 1988). Prolific insecticide use in the 1950s prevented that budworm outbreak from killing stands and resulted in more of the highly vulnerable, mature and over-mature balsam fir stands during the 1970s outbreak. In hindsight, 1950s management could probably have reduced the severity of damage during the 1970 s outbreak. Ideally, this would have included judicious use of insecticides to maintain certain stand types, the "sacrifice" of some stands to budworm to cycle them to a younger age class, and the use of harvesting and silviculture to reduce occurrence of the most vulnerable types.

\section{Past Recommendations - Silvicultural Goals for Budworm Management}

The role of silviculture in spruce budworm management has been discussed in general terms by many authors (Baskerville 1975; Pistell and Harshberger 1979; Flexner et al. 1983; Blum and MacLean 1984, 1985). The problem with all of these references is that rarely, if ever, can recommendations be quantified in terms of their expected reduction in vulnerability (Blum and MacLean 1984); most recommendations are really working hypotheses rather than proven concepts. Treatments are also often insufficiently defined with respect to type, timing, location, and amount.

In general, the past recommendations for silviculture to reduce budworm damage can be summarized as maintaining vigorous stands with rapid growth rates, increasing spruce and/or nonhost content, and removing balsam fir at an early age.

Uneven-aged silviculture would reduce vulnerability only if balsam fir were "selected" out. These treatments maintain a continuous open forest cover of mature trees, which would be ideal for budworm. In mixed spruce-fir or hardwood-fir stand types, frequent (every 10 years) relatively light partial harvests, 

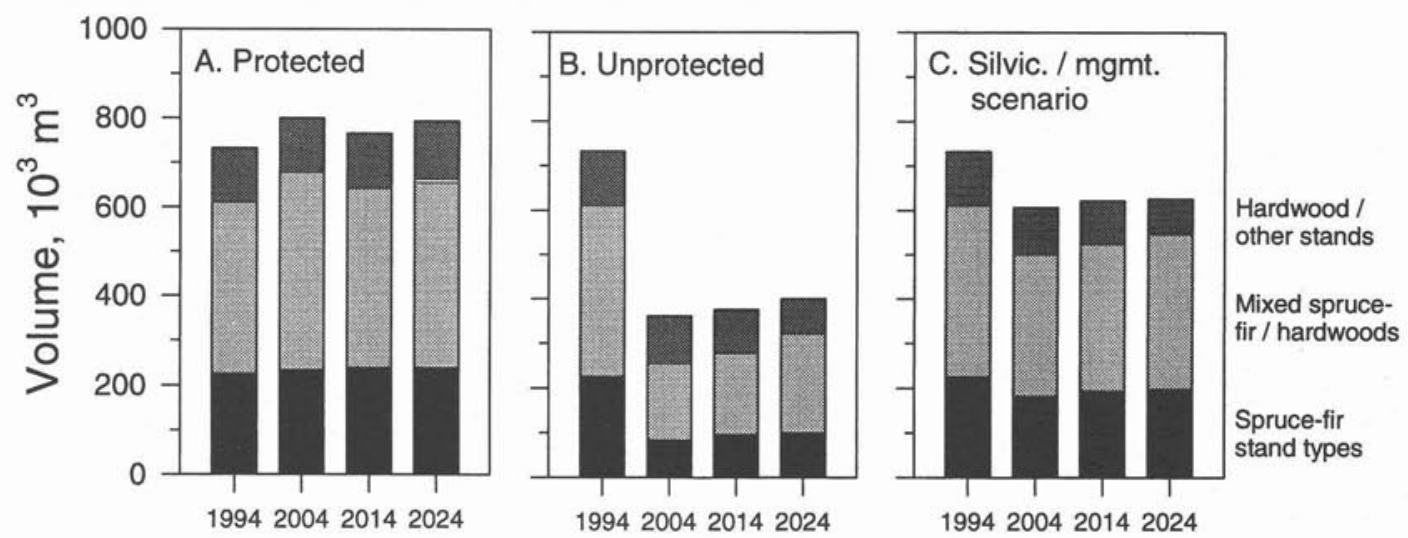

\section{Year}

Fig. 3. Effects of three alternative scenarios on Spruce Budworm DSS projections of spruce-fir volume from 1994-2024 for a 32,000-ha portion of the Fundy Model Forest in southern New Brunswick. A severe spruce budworm outbreak was specified to start in 1994 and last for 12 years. Scenarios A and B show spruce-fir volume development if the forest is protected using insecticides (limiting defoliation to $<40 \%$ of current-year foliage) and if it is unprotected. Scenario $\mathrm{C}$ shows volume development under no insecticide use but with the use of harvesting and planting to convert $50 \%$ of the most vulnerable (xeric and hydric) spruce-fir and mixed spruce-fir/hardwood stands to species with low or no susceptibility (see the text for more details of scenario C).

specifically targeted to remove balsam fir would, through time, reduce damage. Precommercial thinning to discriminate against balsam fir would be effective in reducing damage, but again only in those cases of mixed fir-spruce or mixed fir-hardwood stands.

The regional management strategy recommended to reduce budworm damage over the long term has included maximizing between-stand diversity (a mix of different ages and vulnerable-nonvulnerable stands); attaining a regulated, sustained yield forest; ensuring that site preparation and planting programs use non-host species; and removing balsam fir, both whole stands and in selection harvesting. Blum and MacLean (1984) opined that it will probably still be essential to use insecticides judiciously (not everywhere!) to maintain the desired sustained yield age-class distribution, spatial distribution, and wood supply. Otherwise, a severe spruce budworm outbreak will tend to act as "a great equalizer", converting many stand types to great expanses of even-aged balsam fir forest.

\section{"The Rise and Fall of the Silvicultural Hypothesis in Spruce Budworm Management"}

Miller and Rusnock (1993) published a paper entitled The rise and fall of the silvicultural hypothesis in spruce budworm management. Their stated "silvicultural hypothesis" was that damage caused by budworm was due largely to the disruption of natural ecosystems by forestry practices, and that damage could be significantly reduced by appropriate forest management and silviculture. Miller and Rusnock reviewed the literature on this topic and concluded that over the last decade or so, this hypothesis was widely rejected and was perhaps based on fallacious assumptions. They also concluded that "because these assumptions are relatively impervious to factual information, the debate may not be resolvable by reference to additional scientific information." The main difficulty here is with scale. Manipulations of forest, with the intent of reducing spruce budworm damage, on a large enough spatial or long enough temporal scale to possibly alter budworm outbreak dynamics have never been undertaken and may well never be because of their cost and the large areas involved. Thus Miller and Rusnock felt that, because of logistics, the silvicultural hypothesis may never be adequately tested.

In my opinion, Miller and Rusnock (1993) largely miss the point in their analysis of the silvicultural hypothesis. It is unlikely that budworm outbreaks can ever be prevented entirely by anything other than a major biological control breakthrough, which is not likely to occur over the short term at least. Spruce budworm populations have evolved with eastern spruce-fir forests and budworm outbreaks play a major role in the natural recycling from older spruce-fir to younger age classes (Baskerville 1975; MacLean 1988). In this sense, there is no "disruption of natural ecosystems by forestry practices", although admittedly, as discussed above, the severity of outbreaks has probably increased along with increases in the incidence of balsam fir. So in this sense, my recommendation is to manage the damage!

Current population dynamics theory indicates that spruce budworm outbreaks come and go regardless of the forest, so we cannot prevent outbreaks. However, as discussed above, the vulnerability of different stand types is clear and well documented. Therefore, we can alter the mix of stands with different vulnerability levels in the forest and thereby reduce overall losses and probably reduce the extent of outbreaks. We can conduct forest-level management to minimize damage; the measure could be the aggregate area of severely damaged stands or the $\mathrm{m}^{3}$ of timber lost under alternative management strategies. A DSS that allowed the user to "try" various combinations of protection, harvesting, and silviculture on actual forest data, and to determine the resulting forest-level $\mathrm{m}^{3}$ losses and effects on forest structure and harvest levels would help in designing actions for specific areas of forest. 


\section{Role of a Decision Support System in Managing Budworm Damage}

In the past, several vulnerability rating systems have been developed. MacLean (1985b) reviewed this topic, and differentiated two types: empirical systems based on intuitive observations that produce relative ratings of stands, and quantitative systems that predict the amount of mortality as a function of stand characteristics, through the use of regression equations. Most empirical systems have been qualitative rating schemes, that assign damage classes (e.g. nil, low, moderate, high) on the basis of site, stand, or regional forest composition factors. In a joint project, Blais and Archambault (1982), MacLean (1982), and Raske (1986) developed a regional empirical vulnerability rating and applied it to the provinces of Quebec, New Brunswick, and Newfoundland. Examples of quantitative, regression-based systems include Batzer (1969), MacLean (1980), Batzer and Hastings (1981), and MacLean and Ostaff (1989). One shortcoming of these is that they are based solely on stand structure data (e.g. basal area, percent balsam fir) and do not include site data.

The Spruce Budworm DSS is a forest-level planning tool that incorporates the ARC/Info GIS, a spruce budworm population model, a stand impact model, and systems for vulnerability rating, forest inventory projection, and protection planning. The Spruce Budworm DSS can be used to show "what if" outcomes of alternative combinations of management tactics, including stand-level planting, thinning, selection or shelterwood silviculture, and species-site matching; and forest-level protection, harvest scheduling, altering forest species composition, ageclass distribution, and spatial pattern. The Inventory Projection System allows a user to "grow" their forest inventory up to 30 years in the future, incorporating the effects of two severities of spruce budworm outbreaks, decisions about whether or not to use insecticides during outbreaks, as well as other management options (MacLean and Porter 1995).

The Spruce Budworm DSS also displays interpreted "themes" (Fig. 2), essentially a set of rules that interpret classes such as vulnerability to budworm from inventory or other data. The current implementation of a vulnerability rating in the DSS is very simple, assigning classes on the basis of stand species composition and age class (mature balsam fir $>$ immature balsam fir $>$ mature spruce $>$ immature spruce). A more sophisticated DSS rating system that includes drainage and stand hardwood content is currently under development, including studies to quantify the effects of within-stand hardwood content and surrounding forest species composition on defoliation and stand response to defoliation (described further in a later section of this paper).

\section{Application of the Spruce Budworm DSS to the Fundy Model Forest}

To demonstrate the potential use of the DSS Inventory Projection System and the possible consequences of protection and forest management strategies on losses during a spruce budworm outbreak, three simulations of forest development over a 30-year period for a 32,000-ha portion of the Fundy Model Forest in southern New Brunswick were conducted. The study area consisted of 5791 stands, including 5000 ha of spruce-fir, 10,800 ha of mixed spruce-fir and hardwood stands, 3900 ha of plantations or recently harvested stands, and 12,300 ha of non-susceptible species (primarily hardwoods and pine). In each of the scenarios, a severe spruce budworm outbreak was specified to start in 1994, last for 12 years, and cause mortality and growth losses; forest inventory attributes were examined at 10-year intervals until the year 2024 . In scenario $\mathrm{A}$, stands were protected by spraying insecticide to limit defoliation to less than $40 \%$ of current foliage each year. This would result in small growth losses and possibly even minor increases in mortality rates, but the forest generally remained healthy and relatively static (Fig. 3A). In scenario B, there was no protection during the budworm outbreak, resulting in the loss of $371,000 \mathrm{~m}^{3}$ of spruce-fir volume $(51 \%$ ) by the year 2004 (Fig. 3B). These are similar to actual losses incurred in natural spruce budworm outbreaks (MacLean 1980, 1985a; MacLean and Ostaff 1989). More data on the results of projections of scenarios A and B were presented by MacLean and Porter (1995).

For scenario C, based on increased silviculture/forest management but no use of insecticides, it was assumed that $50 \%$ of the xeric and hydric spruce-fir stands ( $1575 \mathrm{ha}$ ) and mixed spruce-fir/hardwood stands ( $4345 \mathrm{ha}$ ) would be salvage harvested during a 10 -year period and planted with low susceptibility black spruce and non-susceptible jack pine (Pinus banksiana) for hydric and xeric sites, respectively. Because drainage data were not yet implemented, it was assumed that there was an equal distribution of hydric, mesic, subhygric, and xeric site types in the study area. Scenario C, without any insecticide use, reduced losses during the spruce budworm outbreak by $246,000 \mathrm{~m}^{3}$, to a total of $125,000 \mathrm{~m}^{3}$ (Fig. 3C). Thus the unprotected and increased silviculture/forest management scenarios resulted in $51 \%$ and $17 \%$ reductions in spruce-fir volume from 1994-2004, respectively.

Scenario $C$ is presented here as an example of how users could evaluate alternative scenarios rather than as a possible actual strategy. In determining a strategy, relative costs and benefits, as well as timber supply and forest structure consequences, should be evaluated. Scenario C, as stated, would result in harvesting $19 \%$ of the 32,000 -ha area within a 10 -year period, which would probably be excessive. Scenario $\mathrm{C}$ also assumed that a well-developed road network exists to access the forest resource, which is the case for the test area in southern New Brunswick, but would not apply in some other areas. Ideally, it would be possible to use a combination of protection of some areas and less intensive harvesting and stand conversion. A fourth scenario that integrated protection and silviculture/forest management activities would be more realistic, considering the more stringent regulation of insecticide use in most jurisdictions and the fact that such a harvesting level across large areas would be unlikely. The scenario $\mathrm{C}$ example does indicate, however, the potential for managing budworm damage through reduction of occurrence of the most vulnerable species/age/site combinations. All stands are not equal when it comes to budworm damage!

\section{Studies to Refine the Vulnerability Rating System}

Three studies are currently underway to provide additional data for the vulnerability rating system and to evaluate the mechanisms that link stand characteristics to vulnerability to budworm. Each is described briefly below.

In the first study, Wayne MacKinnon (MScF student at the University of New Brunswick) is determining effects of sur- 
rounding forest type (mixedwood versus spruce-fir), tree species (balsam fir versus spruce), and site quality (moist-rich versus wet-poor) on amount of defoliation and growth response to the measured defoliation. Two hypotheses are being tested: 1) defoliation is affected by surrounding forest type (softwood $>$ mixedwood), species (balsam fir $>$ spruce), and site (wet/poor > moist/rich); and 2) growth response to defoliation is affected by species (balsam fir > spruce) and site (wet/poor $>$ moist/rich). Forty balsam fir stands, selected on the basis of species composition, site type, and surrounding (within 1 kilometer) forest type were sampled in northern New Brunswick and defoliation levels and growth response were evaluated for a 5-year period; data analyses are underway.

In the second study, Qiong $\mathrm{Su}$ (also a MScF student at the University of New Brunswick) is determining effects of within-stand hardwood content on balsam fir growth, amount of defoliation of balsam fir, and the impact of defoliation on balsam fir. Twenty-five mixed balsam fir-hardwood stands were selected in northern New Brunswick, with five stands in each $20 \%$ hardwood content classes (0-20\%, 21-40\%, etc.). Analyses indicated that defoliation each year from 1989 to 1993 was significantly $(\mathrm{p}<0.0001)$ negatively related to hardwood content, with $\mathrm{r}^{2}$ ranging from 0.57 to 0.81 (Su et al. 1996). From 1989 to 1992 , the years of moderate-severe defoliation, balsam fir stands with $<40 \%$ hardwoods averaged $58-71 \%$ defoliation, versus $12-15 \%$ defoliation in stands with $>80 \%$ hardwoods. A generalized model combining hardwood content and the estimated defoliation in pure softwood stands in a given year explained $77 \%$ of the variation in defoliation for stands and years (Su et al. 1996). This study indicated that mixed balsam fir-hardwood stand management, with hardwood content $>40 \%$, could substantially reduce losses during spruce budworm outbreaks. Su et al. hypothesized that the mechanism involved a higher diversity and density of spruce budworm natural enemies such as birds and parasitoids in stands with greater hardwood content. Growth data analyses from the project are still underway.

The third study is long term, and involves the establishment of mixed hardwood-softwood plantations that ultimately will be used for studies of susceptibility and vulnerability to insects. With funding from the Fundy Model Forest and the cooperation of H.A. Fawcett \& Sons Ltd. in Petitcodiac, New Brunswick, 24 ha of mixed species plantations were established. White spruce, black spruce, and Norway spruce were planted, and initial planting density and precommercial spacing of the natural white birch-maple-poplar regeneration on the site was used to achieve replicated blocks of four softwoodhardwood mixes: pure softwood, two-thirds softwood, onethird softwood, and pure hardwood. This will provide a valuable research site for studies of effects of hardwood content on mixed stand growth and yield, vulnerability to insects (spruce budworm, spruce bud moth, white pine weevil), and understorey vegetation and insect biodiversity. These stands will be available for both manipulative and natural insect outbreak studies. If such mixed stands had been established in the past and studied during spruce budworm outbreaks, more would be known about the factors that determine vulnerability.

\section{Conclusions}

For the foreseeable future, it will not be possible to prevent spruce budworm outbreaks, but the damage that occurs can be managed. Tree species, stand age, hardwood content, and drainage class all determine the amount of mortality during budworm outbreaks, and silviculture/forest management can be used to reduce the incidence of the most damaged stand types. There is a role for DSS here, in evaluating effects of alternative management actions and severities of budworm outbreaks on forest structure and timber supply. An example presented for a portion of the Fundy Model Forest indicated that losses from a hypothetical budworm outbreak could be reduced $34 \%$ by directing harvesting and silviculture towards conversion of the most vulnerable stand types into species with low or no susceptibility.

Also, to progress beyond Craighead's (1924) nonspecific statement that "the answer to the budworm problem is forest management" we need to determine the mechanisms of vulnerability and have some on-the-ground tests in place before a future spruce budworm outbreak. One significant step forward was the recent finding that the amount of defoliation in mixed balsam fir-hardwood stands is strongly negatively related to hardwood content, especially with hardwoods $>40 \%$ (Su et al. 1996).

\section{Acknowledgments}

The spruce budworm DSS has been financially supported by the Canada Green Plan "Partners for Sustainable Development" Program, with cost sharing by the Integrated Forest Pest Management and Decision-Support System initiatives. I wish to thank Kevin Porter, Thom Erdle, and Ian DeMerchant, who have made major contributions to the project, and also thank Jeff Kerr and Wayne MacKinnon, who assisted with the Fundy Model Forest IPS analyses.

\section{References}

Baskerville, G.L. 1975. Spruce budworm: super silviculturist. For. Chron. 51: 138-140.

Baskerville, G.L. and S. Kleinschmidt. 1981. A dynamic model of growth in defoliated fir stands. Can. J. For. Res. 11: 206-214.

Baskerville, G.L. and D.A. MacLean. 1979. Budworm-caused mortality and 20-year recovery in immature balsam fir stands. Can. For. Serv., Fredericton, NB. Inf. Rep. M-X-102.

Batzer, H.O. 1969. Forest character and vulnerability of balsam fir to spruce budworm in Minnesota. For. Sci. 15: 17-25.

Batzer, H.O. and A.R. Hastings. 1981. Rating spruce-fir stands for spruce budworm vulnerability in Minnesota. pp. 105-108. In Hazard rating systems in forest insect pest management: Symp. Proc. R.L. Hedden, S.J. Barras and J.E. Coster (tech. coords.). USDA For. Serv., Washington, DC. Gen. Tech. Rep. WO-27.

Blais, J.R. 1983. Trends in the frequency, extent, and severity of spruce budworm outbreaks in eastern Canada. Can. J. For. Res. 13: 539-547. Blais, J.R. and L. Archambault. 1982. Rating vulnerability of balsam fir to spruce budworm attack in Quebec. Can. For. Serv., Ste. Foy, PQ. Inf. Rep. LAU-X-51.

Blum, B.M. and D.A. MacLean. 1984. Silviculture, forest management, and the spruce budworm. Chapter 6. pp. 83-102. In Managing the spruce budworm in eastern North America. D.M. Schmitt, D.G. Grimble and J.L. Searcy (Eds.). USDA For. Serv., Washington, DC. Agric. Handb. 620.

Blum, B.M. and D.A. MacLean. 1985. Potential silviculture, harvesting and salvage practices in eastern North America. pp. 264-280. In Recent advances in spruce budworms research. Proc. CANUSA Spruce Budworms Research Symp., 16-20 Sept. 1984, Bangor, ME. C.J. Sanders, R.W. Stark, E.J. Mullins and J. Murphy (Eds.). Can. For. Serv., Ottawa, ON.

Craighead, F.C. 1924. Studies on the spruce budworm (Cacoecia 
fumiferana Clem.). Part II. General bionomics and possibilities of prevention and control. Tech. Bull. 37 (N.S.) Can. Dep. of Agric., Ottawa, ON. pp. 28-91.

DeMerchant, I. 1994. Inventory projection system. Co-op project report. College of Geographic Sciences, Lawrencetown, NS.

Dupont, A., L. Bélanger and J. Bousquet. 1991. Relationships between balsam fir vulnerability to spruce budworm and ecological site conditions of fir stands in central Québec. Can. J. For. Res. 21: $1752-1759$.

Flexner, J.L., J.R. Bassett, B.A. Montgomery, G.A. Simmonds and J.A. Witter. 1983. Spruce-fir silviculture and the spruce budworm in the Lake States. Univ. Michigan School Nat. Resources, Ann Arbor, MI. Handbook 83-2. 30 p.

Hix, D.M., B.V. Barnes, A.M. Lynch and J.A. Witter. 1987. Relationships between spruce budworm damage and site factors in spruce-fir dominated ecosystems of western Upper Michigan. For. Ecol. Mgmt. 21: 129-140.

Kettela, E.G. 1983. A cartographic history of spruce budworm defoliation 1967 to 1981 in eastern North America. Can. For. Serv., Ottawa, ON. Inf. Rep. DPC-X-14.

MacLean, D.A. 1980. Vulnerability of fir-spruce stands during uncontrolled spruce budworm outbreaks: a review and discussion. For. Chron. 56: 213-221.

MacLean, D.A. 1982. Vulnerability rating of forests in New Brunswick and Nova Scotia to budworm attack. Can. For. Serv., Fredericton, NB. Inf. Rep. M-X-132.

MacLean, D.A. 1985a. Effects of spruce budworm outbreaks on forest growth and yield. pp. 148-175. In Recent advances in spruce budworms research. Proc. CANUSA Spruce Budworms Research Symp. 16-20 Sept. 1984, Bangor, ME. C.J. Sanders, R.W. Stark, E.J. Mullins and J. Murphy (Eds.). Can. For. Serv., Ottawa, ON.

MacLean, D.A. 1985b. Predicting the risk of spruce budworm damage using hazard and vulnerability rating systems. pp. 113-120. In Spruce-fir management and spruce budworm. USDA For. Serv., Broomall, PA. Gen. Tech. Rep. NE-99.

MacLean, D.A. 1988. Effects of spruce budworm outbreaks on vegetation, structure, and succession of balsam fir forests on Cape Breton Island, Canada. pp. 253-261. In Plant form and vegetation structure. M.J.A. Werger, P.J.M. van der Aart, H.J. During and J.T.A. Verhoeven (Eds.). SPB Academic Publishing, The Hague, Netherlands.

MacLean, D.A. 1990. Impact of forest pests and fire on stand growth and timber yield: implications for forest management planning. Can. J. For. Res. 20: 391-404.

MacLean, D.A. and D.P. Ostaff. 1983. Sample size - precision relationships for use in estimating stand characteristics and spruce budworm caused tree mortality. Can. J. For. Res. 13: 548-555.

MacLean, D.A. and D.P. Ostaff. 1989. Patterns of balsam fir mortality caused by an uncontrolled spruce budworm outbreak. Can. J. For. Res. 19: 1087-1095.
MacLean, D.A. and H. Piene. 1995. Spatial and temporal patterns of balsam fir mortality in spaced and unspaced stands caused by spruce budworm defoliation. Can. J. For. Res. 25: 902-911. MacLean, D.A. and K.B. Porter. 1994. Development of a decision support system for spruce budworm and forest management planning in Canada. pp. 863-872. In Decision making With GIS - The fourth dimension. Vol. 2. Proc. GIS ' 94 Symp., Vancouver, BC.

MacLean, D.A. and K.B. Porter. 1995. A DSS for budworm and forest management planning: maximizing protection benefits and forecasting inventories. pp. 530-540. In Proceedings Decision Support 2001, Sept. 12-16, 1994, Toronto, Ont. J.M. Power, M. Strome and T.C. Daniel (Eds.). Amer. Soc. Photogrammetry and Remote Sensing, Bethesda, MD.

Miller, A. and P. Rusnock. 1993. The rise and fall of the silvicultural hypothesis in spruce budworm (Choristoneura fumiferana) management in eastern Canada. Forest Ecol. Mgmt. 61: 171-189.

Osawa, A. 1989. Causality in mortality patterns of spruce trees during a spruce budworm outbreak. Can. J. For. Res. 19: 632-638.

Osawa, A., C.J. Spies and J.B. Dimond. 1986. Patterns of tree mortality during an uncontrolled spruce budworm outbreak in Baxter State Park, 1983. Life Sci. Agric. Exp. Sta., Maine. Tech. Bull. No. 121. Ostaff, D.P. and D.A. MacLean. 1995. Patterns of balsam fir foliar production and growth in relation to defoliation by spruce budworm. Can. J. For. Res. 25: 1128-1136.

Piene, H. 1980. Effects of insect defoliation on growth and foliar nutrients of young balsam fir. For. Sci. 26: 665-673.

Pistell, A. and D. Harshberger. 1979. The spruce budworm in Maine: a history of forest conditions, forest industry and policy from 1800-1981. Dep. Cons., Maine For. Serv., Augusta, ME.

Raske, A.G. 1986. Vulnerability rating of the forest of Newfoundland to spruce budworm damage. Can. For. Serv., St. John's, Nfld. Inf. Rep. N-X-239.

Royama, T. 1984. Population dynamics of the spruce budworm, Choristoneura fumiferana. Ecol. Monogr. 54: 429-462.

Royama, T. 1992. Analytical population dynamics. Population and Community Biology Series 10. Chapman and Hall, London. $371 \mathrm{p}$. Steinman, J.R. and D.A. MacLean. 1994. Predicting effects of defoliation on spruce-fir stand development: a management-oriented growth and yield model. For. Ecol. Mgmt. 69: 283-298.

Su, Q., D.A. MacLean and T.D. Needham. 1996. The influence of hardwood content on balsam fir defoliation by spruce budworm. Can. J. For. Res. 26: in press.

Vanguard Forest Management Services Ltd. 1993a. Forest protection planning to sustain long-term wood supplies. Contract Report to Can. For. Serv., Maritimes Region, Fredericton, NB.

Vanguard Forest Management Services Ltd. 1993b. STAMAN stand growth model and Calibration of STAMAN model for defoliation impacts. pp. B1-B39, C1-C18. In Forest protection planning to sustain long-term wood supplies. Contract Report to Can. For. Serv., Maritimes Region, Fredericton, NB. 